\title{
Nowotwory mieloproliferacyjne i zespoły mielodysplastyczne - postępy w diagnostyce i terapii
}

\author{
Myeloproliferative neoplasms and myelodysplastic syndromes \\ - advances in diagnosis and therapy
}

Joanna Góra-Tybor

Klinika Hematologii, Instytut Hematologii i Transfuzjologii, Warszawa

\begin{abstract}
Streszczenie
W ostatnich latach dokonat sie bardzo duży postęp $w$ zakresie diagnostyki $i$ terapii nowotworów mieloproliferacyjnych $i$ zespotów mielodysplastycznych. Dostępność nowych technik sekwencjonowania pozwolita na zidentyfikowanie licznych mutacji somatycznych sktadajacych sie na ztożony obraz molekularny tej grupy nowotworów. Poznanie mechanizmów patogenetycznych zaowocowato z kolei rozwojem skutecznych terapii celowanych. Jednocześnie sq konstruowane nowe skale prognostyczne, które pozwalaja na właściwa kwalifikacje pacjentów do odpowiedniego rodzaju terapii.
\end{abstract}

Słowa kluczowe: czerwienica prawdziwa, nadpłytkowość samoistna, pierwotna mielofibroza, zespoły mielodysplastyczne, skale prognostyczne, leczenie

Hematologia 2015; 6, 1: 70-76

\begin{abstract}
During recent years there has been a significant progress in the diagnosis and therapy of myeloproliferative neoplasms and myelodysplastic syndromes. The application of novel sequencing techniques has led to the discovery of multiple recurrently mutated genes that has largely improved our understanding of the biological complexity of these malignancies. Most importantly, these new findings on molecular pathogenesis have resulted in the development of effective targeted therapies as well as construction of new prognostic indexes that facilitate patients' assignment to proper type of treatment.
\end{abstract}

Key words: polycythemia vera, essential thrombocythemia, primary myelofibrosis, myelodysplastic syndromes, prognostic scales, therapy

Hematologia 2015; 6, 1: 70-76

\section{Wprowadzenie}

Na łamach czasopisma „Hematologia” co roku są publikowane podsumowania dotyczące najważniejszych doniesień prezentowanych na konferencji ASH (American Society of Hematology). Wiele informacji okazuje się bardzo ważnych dla wiedzy o danej chorobie, niektóre wpływają na zmianę standardów leczenia, a inne, zweryfikowane przez czas i wyniki kolejnych badań, okazują się nieistotne. $W$ tym artykule podsumowano najważniejsze osiągnięcia $\mathrm{w}$ diagnostyce i leczeniu chorych na nowotwory mieloproliferacyjne (MPN, myeloproliferative neoplasms) bez obecności genu $B C R-A B L 1$ (MPN BCR-ABL1[-]), a także postęp, jaki się dokonał w tym zakresie w ostatnich latach

Adres do korespondencji: Joanna Góra-Tybor, Klinika Hematologii, Instytut Hematologii i Transfuzjologii, ul. Indiry Gandhi 14, 02-776 Warszawa, tel. 223496 334, faks 223496 327, e-mail: email: joannagora@op.pl 
w zespołach mielodysplastycznych (MDS, myelodysplastic syndromes).

\section{Nowotwory mieloproliferacyjne $B C R-A B L 1(-)$}

\section{Patogeneza}

W 2008 roku Światowa Organizacja Zdrowia (WHO, World Health Organization) wprowadziła wiele zmian do klasyfikacji MPN [1], co stało się możliwe dzięki zrozumieniu związku między obecnością określonych zaburzeń molekularnych a wystąpieniem objawów charakterystycznych dla ich poszczególnych postaci. Kluczowe znaczenie $\mathrm{w}$ tym zakresie miało odkrycie mutacji V617F eksonu 14 genu kinazy tyrozynowej JAK2 - defektu, którego obecność potwierdzono u ponad 95\% chorych z czerwienicą prawdziwą (PV, polycythemia vera), 55\% chorych na nadpłytkowość samoistną (ET, essential thrombocythemia) i $65 \%$ chorych na pierwotną mielofibrozę (PMF, primary myelofibrosis) [2]. Kinaza JAK2 należy do cytoplazmatycznych kinaz tyrozynowych i jest elementem szlaku sygnałowego zależnego od receptorów cytokinowych, prowadzącego do aktywacji czynników transkrypcyjnych STAT (signal transducers and activators of transcription). Wkrótce okazało się, że patogeneza molekularna MPN BCR-ABL1(-) jest bardziej złożona, a mutacja V617F genu JAK2 w obrębie eksonu 14 nie reprezentuje jedynego ani pierwotnego defektu molekularnego w MPN; u około 3\% chorych na PV mutacja JAK dotyczy eksonu 12, a u 3-5\% chorych na ET i 5-10\% na PMF występuje dodatkowo mutacja W515L/K w obrębie genu receptora dla trombopoetyny (MPL, myeloproliferative leukemia virus oncogene) [3].

W 2013 roku dwie niezależne grupy badawcze zidentyfikowały mutacje somatyczne nowego onkogenu CALR (calreticulin), kodującego białko (kalretikulinę), występujące u około $80 \%$ pacjentów z ET i PMF niebędących nosicielami mutacji JAK2 ani $M P L$ [4, 5]; CALR jest wysoce konserwatywnym białkiem zaangażowanym $\mathrm{w}$ różnorodne procesy istotne dla funkcjonowania komórki, takie jak proliferacja i apoptoza. Zlokalizowana w retikulum endoplazmatycznym CARL kontroluje prawidłowe składanie glikoprotein i moduluje homeostazę wapniową [6]. Co istotne, wszystkie opisane mutacje CARL dotyczyły eksonu 9; najczęściej stwierdzano dwa warianty: L367fs*46 (delecja 52-bp) (typ 1 mutacji) i K385fs*47 (insercja 5-bp) (typ 2 mutacji). W każdym przypadku dochodzi do przesunięcia ramki odczytu, co prowadzi do zmiany C-końcowej sekwencji białka $z$ utratą motywu
KDEL (endoplasmic reticulum retention signal). Zmiana C-końcowej sekwencji CALR i utrata motywu KDEL wiąże się między innymi ze zmianą polaryzacji białka, zwiększeniem zasadowości i utratą większości miejsc wiążących jony $\mathrm{Ca}^{2+}$, a także zwiększoną fosforylacją i aktywacją szlaku sygnałowego JAK-STAT. W dalszych badaniach obejmujących sekwencjonowanie genomu i eksomu potwierdzono obecność mutacji CALR u 110 spośród 158 pacjentów z MPN BCR-ABL1(-) bez mutacji JAK2 lub MPL (70\%; 95-proc. przedział ufności [CI, confidence interval]; 62-77), w tym u 80/112 chorych na ET (71\%), 18/32 chorych na PMF (56\%) i 12/14 pacjentów z progresją ET do MF (86\%). U żadnego spośród 511 chorych na MPN z mutacją JAK2 lub MPL nie stwierdzono mutacji $C A L R$. Ponadto mutacje $C A L R$ zidentyfikowano u 10/120 pacjentów z MDS, 1/33 pacjentów $z$ przewlekłą białaczką mielomonocytową (CMML, chronic myelomonocytic leukemia) i $1 / 29 \mathrm{z}$ atypową przewlekłą białaczką szpikową (aCML, atypical chronic myelogenous leukemia). Mutacji CALR nie znaleziono u żadnego chorego $\mathrm{z}$ nowotworem układu chłonnego, $z$ guzem litym ani w zdrowej grupie kontrolnej.

Analiza przebiegu ET u pacjentów $z$ obecnością mutacji $C A L R$ wykazała, że w porównaniu $z$ chorymi na ET $z$ dodatnią mutacją JAK2 charakteryzują się oni młodszym wiekiem, niższą leukocytozą, większą liczbą płytek oraz niższym ryzykiem powikłań zakrzepowych [7-9]. Z kolei pacjenci z PMF mający mutacje $C A R L$ również charakteryzują się niższą leukocytozą i większą liczba płytek, a ponadto czas przeżycia (OS, overall survival) jest u nich istotnie dłuższy niż u chorych $J A K(+)$ i $M P L(+)$. W przypadku PMF szczególnie źle rokują tak zwani pacjenci potrójnie negatywni, czyli bez mutacji JAK, CARL i MPL. Cechują ich istotnie skrócony OS i zwiększone ryzyko transformacji białaczkowej [7, 10].

Podsumowując, mutacja $C A R L$ ma bardzo istotne znaczenie w patogenezie MPN, co najprawdopodobniej zostanie uwzględnione w nowych kryteriach diagnostycznych klasyfikacji WHO. Ponadto pełni ważną rolę rokowniczą i w przyszłości może się stać celem terapeutycznym.

Spośród klasycznych MPN BCR-ABL1(-) szczególnie złożony obraz molekularny charakteryzuje PMF. Poza omówionymi zmianami genetycznymi w patogenezie PMF istotną rolę odgrywają mutacje genów zaangażowanych w mechanizmy epigenetyczne. Należą do nich mutacje genów biorących udział $\mathrm{w}$ procesach potranslacyjnej modyfikacji histonów (ASXL1, częstość 10-35\%; 
EZH2, częstość 7-10\%), metylacji DNA (TET2, DNMT3A, IDH1/2), splicingu mRNA (SRFS2, $S R F 3 B 1)$ oraz procesach naprawy DNA (TP53) [11-13].

\section{Wskaźniki rokownicze}

Spośród MPN BCR-ABL1(-) PMF jest chorobą o najgorszym rokowaniu. $\mathrm{W}$ ostatnich latach powstało wiele wskaźników prognostycznych ułatwiających decyzje terapeutyczne u tych chorych. Zaproponowany w 2009 roku Międzynarodowy Wskaźnik Prognostyczny (IPSS, International Prognostic System Score) uwzględnia wiek chorego, stężenie hemoglobiny poniżej $10 \mathrm{~g} / \mathrm{dl}$, liczbę leukocytów powyżej $25 \mathrm{G} / 1$, obecność we krwi obwodowej co najmniej $1 \%$ blastów i występowanie objawów ogólnych [14]. Jego modyfikacją jest dynamiczny IPSS (DIPSS) umożliwiający ocenę pacjenta nie tylko w chwili rozpoznania, ale również w dowolnym momencie trwania choroby [15]. Najnowszy wskaźnik, DIPSS plus, uwzględnia trzy dodatkowe parametry: zapotrzebowanie na transfuzje koncentratu krwinek czerwonych (kkcz), liczbe płytek krwi ponizej $100 \mathrm{G} / 1$ oraz niekorzystny kariotyp, który charakteryzuje się obecnością złożonych anomalii cytogenetycznych $(>3)$ lub $+8,-7 / 7 \mathrm{q}-$, i(17q), inv(3), -5/5q-, 12p-, q23 [16].

Wraz $z$ postępem wiedzy na temat profilu zmian molekularnych w PMF stało się jasne, że obecność pewnych mutacji jest istotnym czynnikiem rokowniczym dla OS. Vannucchi i wsp. [11] ocenili wpływ mutacji $A S X L 1, S R S F 2, E Z H 2$, TET2, DNMT3A, CBL,IDH1,IDH2, MPL i JAK2 na przeżycie 898 pacjentów z PMF. Spośród badanych mutacji $A S X L 1, S R S F 2$ i EZH2 wykazywały negatywny wpływ na OS, przy czym obecność mutacji ASXL1 wykazywała wpływ niezależny od IPSS i DIPSS. Ponadto pacjentów z obecnością mutacji IDH1/2, SRSF2 i ASXL1 cechowało zwiększone ryzyko transformacji białaczkowej. Tefferi i wsp. [10] opracowali model prognostyczny oparty na obecności mutacji CARL (korzystne rokowanie) i ASXL1 (niekorzystny czynnik prognostyczny), który okazał się niezależny od DIPSS plus ( $p<0,0001)$ i szczególnie przydatny dla identyfikacji źle rokujących pacjentów $z$ grup ryzyka niskiego i pośredniego-1. Analiza wielowariancyjna wykazała, że obecność mutacji $A S X L 1$ przy nieobecności mutacji $C A R L$ jest najistotniejszym niekorzystnym czynnikiem ryzyka dla OS. Trwają próby konstruowania wskaźników prognostycznych opartych przede wszystkim na zmianach cytogenetycznych i molekularnych. Na Konferencji ASH w 2014 roku przedstawiono propozycje wskaźnika prognostycz- nego uwzględniającego obecności mutacji (MIPSS, mutation-enhanced international prognostic scoring system) oraz systemu prognostycznego uwzględniającego jednocześnie obecności mutacji i zmian w kariotypie u pacjentów z PMF (GPSS, genetic international prognostic scoring system) [17, 18].

\section{Leczenie}

Powszechne występowanie mutacji JAK2 w przebiegu MPN, a także obserwowana hiperaktywacja drogi sygnałowej JAK-STAT stanowiły racjonalny powód do podjęcia badań nad rozwojem i oceną skuteczności jej inhibitorów. Trwają dwa randomizowane badania 3. fazy (COMFORT I i COMFORT II) $z$ udziałem chorych na PMF służące ocenie skuteczności ruksolitynibu (inhibitorów JAK1 i JAK2). Do obu badań włączono chorych $z$ grupy pośredniego-2 i wysokiego ryzyka według IPSS, porównując ruksolitynib $z$ placebo (COMFORT I) lub najlepszą dostępną terapią (COMFORT II) [19, 20].

W obu badaniach u chorych leczonych ruksolitynibem obserwowano istotną redukcję rozmiarów śledziony, a także zmniejszenie nasilenia objawów ogólnych u około połowy pacjentów. Wykazano również przedłużenie OS pacjentów leczonych ruksolitynibem w porównaniu $z$ chorymi otrzymującymi placebo lub najlepszą dostępną terapię. Najczęstsze objawy niepożądane 3 . lub 4. stopnia związane $z$ lekiem to małopłytkowość i niedokrwistość występujące u około $40 \%$ chorych. W przebiegu dłuższej obserwacji pacjentów otrzymujących ruksolitynib zmniejszyła się liczba chorych wymagających przetoczeń kkcz, a liczba nowych chorych, u których obserwowano niedokrwistość i małopłytkowość 3. lub 4. stopnia, była niewielka. W obu badaniach wykazano dłuższy OS w grupie leczonej ruksolitynibem. Jest to obserwacja warta podkreślenia, tym bardziej że większość pacjentów z grupy otrzymującej placebo lub najlepszą dostępną terapię przeszło z czasem do grupy leczonej ruksolitynibem (crossover). Wyniki badań COMFORT stanowiły podstawę zarejestrowania ruksolitynibu przez FDA (Food and Drug Administration) w Stanach Zjednoczonych oraz przez Europejską Agencję ds. Leków (EMA, European Medicines Agency) w Unii Europejskiej do leczenia chorych na PMF obciążonych ryzykiem pośrednim-2 $\mathrm{i}$ wysokim.

Spośród nowych leków stosowanych u chorych na PMF zwraca uwagę momelotynib (CYT387) — inhibitor JAK1 i JAK2 oraz pakrytynib (SB1518) — inhibitor JAK2 i FLT3 [21]. Zastosowanie obu inhibitorów prowadzi do szybkiego zmniejszenia rozmiarów powiększonej śledziony i ustąpienia ob- 
jawów ogólnych choroby u około połowy leczonych chorych. Co istotne, oba leki powodują poprawę parametrów morfologii krwi obwodowej, a także uniezależnienie od przetoczeń kkcz [21].

Inhibitory kinazy JAK znalazły także zastosowanie w leczeniu chorych na PV. Vannucchi i wsp. [22] opublikowali wyniki randomizowanego badania 3. fazy, w którym porównywano skuteczność ruksolitynibu i standardowej terapii (ST) w grupie 222 pacjentów opornych na hydroksymocznik (HU, hydroxyurea) lub go nietolerujących. Celem pierwszorzędowym badania było uniezależnienie od krwioupustów (hematokryt [Ht] < 45\%) i zmniejszenie śledziony o co najmniej 35\% w 32 . tygodniu leczenia. Cel pierwszorzędowy spełniło $21 \%$ pacjentów w grupie leczonej ruksolitynibem i $1 \% \mathrm{w}$ grupie poddanej ST $(\mathrm{p}<0,001)$. Kontrolę Ht osiagnnięto odpowiednio u $60 \%$ i $20 \%$ pacjentów w grupach leczonych ruksolitynibem oraz ST. Całkowitą odpowiedź hematologiczną (CHR, complete hematologic response) stwierdzono u $24 \%$ chorych leczonych ruksolitynibem i $9 \% \mathrm{w}$ grupie ST $(p=0,003)$. Ponadto $\mathrm{w}$ grupie leczonej ruksolitynibem obserwowano istotnie lepszą kontrolę objawów ogólnych i objawów związanych z zaburzeniami mikrokrążenia $(50 \%$ v. 5\%). Tolerancja leczenia była dobra; w grupie leczonej ruksolitynibem obserwowano niedokrwistość 3. i 4. stopnia u $2 \%$ pacjentów i małopłytkowość 3. i 4. stopnia u 5\%; w grupie leczonej ST odpowiednie odsetki wynosiły $0 \%$ i $4 \%$. U pacjentów leczonych ruksolitynibem częściej obserwowano zakażenia Herpes Zoster $(6 \%$ v. $0 \%$ ). Wyniki badania stanowity podstawę do rejestracji ruksolitynibu przez FDA i EMA w leczeniu chorych na PV opornych lub nietolerujących HU.

Należy także wspomnieć o istotnej roli interferonu $\alpha(\operatorname{IFN} \alpha)$ w leczeniu chorych na PV i ET. Stosowanie go pozwala na uzyskanie CHR u większości leczonych chorych, a ponadto powoduje zmniejszenie ilości alleli JAK2 +. U części pacjentów obserwowano długie okresy remisji po zaprzestaniu leczenia. Terapia za pomocą IFN częściej niż klasycznymi lekami cytostatycznymi powoduje zniesienie objawów ogólnych PV, zwłaszcza świądu oraz objawów związanych $z$ zaburzeniami mikrokrążenia, takich jak erytromelalgia i parestezje. Niestety, u znacznego odsetka chorych IFN $\alpha$ powoduje objawy niepożądane będące przyczyną odstawienia leku u 20-25\% pacjentów. Można przypuszczać, że wprowadzenie do terapii interferonów pegylowanych (PEG) pozwoli na zmniejszenie toksyczności. Wyniki rozpoczętego niedawno międzynarodowego randomizowanego badania 3. fazy, służącego porównaniu skuteczności i toksyczności PEG-IFN $\alpha$-2A z HU w I linii leczenia u chorych na ET i PV, pozwolą na określenie jego właściwego miejsca w terapii tych chorych [23, 24].

\section{Zespoły mielodysplastyczne}

\section{Patogeneza}

Dostępność nowych technik sekwencjonowania pozwoliła na zidentyfikowanie licznych mutacji somatycznych składających się na złożony obraz molekularny MDS. W patogenezie MDS istotną rolę odgrywają mutacje genów zaangażowanych w mechanizmy epigenetyczne. Należą do nich mutacje genów biorących udział w procesach potranslacyjnej modyfikacji histonów (ASXL1, częstość $15 \%$; EZH2; częstość $5 \%$ ), metylacji DNA (TET2, częstość 20\%; DNMT3A, częstość $12 \%$; IDH1/2, częstość 5\%), splicingu mRNA (SRFS2, częstość 12\%; SRF3B1, częstość 18\%) oraz procesach naprawy DNA (TP53, 5\%) [25-27]. Zidentyfikowanie tych mutacji potwierdziło kluczową rolę mechanizmów epigenetycznych w patogenezie MDS. Na podkreślenie zasługuje negatywne znaczenie mutacji TP53; charakteryzuje ona pacjentów $z$ MDS ze zwiększonym odsetkiem blastów, małopłytkowością i złożonym kariotypem. Obecność mutacji TP53 u chorych na MDS przebiegający $z$ izolowaną del5q(-) wiąże się z mniejszym odsetkiem odpowiedzi na lenalidomid i częstszą progresją do ostrej białaczki szpikowej (AML, acute myeloid leukemia) [28]. Wykazano, że również obecność innych mutacji, zwłaszcza ASXL1, DNMT3A, EZH2 i RUNX1, wiąże się $z$ krótszym OS i wyższym ryzykiem transformacji do AML. Z kolei mutacja SF3B1 charakteryzuje MDS z obecnością pierścieniowych syderoblastów $\mathrm{i}$ indolentnym przebiegiem choroby [25-27]. Trwają próby uwzględnienia obecności mutacji we wskaźnikach rokowniczych u chorych na MDS.

\section{Wskaźniki rokownicze}

Wskaźniki rokownicze, według których ocenia się ryzyko chorych na MDS, to przede wszystkim zaproponowany w 1997 roku IPSS i w 2005 roku WPSS (WHO classification-based prognostic scoring system) [29, 30]. W 2012 roku Greenberg i wsp. [31] zaproponowali zmodyfikowany IPSS (IPSS-R, IPSS revisited) definiujący pięć grup ryzyka: bardzo niskiego, niskiego, pośredniego, wysokiego $\mathrm{i}$ bardzo wysokiego, $\mathrm{z}$ medianami czasu przeżycia wynoszącymi odpowiednio 8,8; 5,3; 3; 1 ,6 i 0,8 roku. Nowa klasyfikacja bardziej szczególowo charakteryzuje grupy ryzyka cytogenetycznego, głębokość cytopenii i liczbę blastów w szpiku kostnym. Liczne 
analizy retrospektywne wykazały, że IPSS-R pozwala lepiej prognozować OS i ryzyko transformacji do AML niż dotychczas stosowane skale IPSS i WPSS [32-34].

Mishra i wsp. [32] oceniali przydatność IPSS-R w grupie 1088 chorych na MDS. Mediana obserwacji wynosiła 70 miesięcy; zgodnie $z$ IPSS-R mediany OS w grupach ryzyka bardzo niskiego, niskiego, pośredniego, wysokiego i bardzo wysokiego wynosily odpowiednio 90, 54, 34, 21 i 13 miesięcy $(\mathrm{p}<0,005)$. Wskaźnik ten okazał się również przydatny do oceny przeżycia w grupie 618 pacjentów otrzymujących leki hipometylujące. Istotne wydłużenie OS w grupie pacjentów leczonych azacytydyną obserwowano $\mathrm{w}$ grupach wysokiego (mediana OS $25 v .18$ miesięcy; p < 0,028) i bardzo wysokiego ryzyka według IPSS-R (mediana OS $15 v .9$ miesięcy; $\mathrm{p}=0,005$ ). Wydłużenie OS w grupie chorych, u których wykonano przeszczepienie allogenicznych krwiotwórczych komórek macierzystych (allo-HSCT, allogeneic hematopoietic stem cells transplantation) również dotyczyło pacjentów $z$ grup wysokiego (mediana OS 40 v. 19 miesięcy; $\mathrm{p}<0,005)$ i bardzo wysokiego ryzyka (mediana OS $31 v .12$ miesięcy; $\mathrm{p}<0,005)$. W aktualnych zaleceniach NCCN (National Comprehensive Cancer Network) stosowanie IPSS-R rekomenduje się u chorych na MDS [35].

\section{Leczenie}

W ostatnich latach obserwuje się istotną poprawę wyników leczenia chorych na MDS. Wynika ona przede wszystkim $z$ bardziej precyzyjnego rozpoznawania i prognozowania przebiegu klinicznego tej grupy chorób na podstawie klasyfikacji WHO i wskaźników rokowniczych $[1,29]$ oraz wprowadzenia do terapii nowych leków, przede wszystkim lenalidomidu dla chorych na MDS przebiegające $z$ nieprawidłowościami cytogenetycznymi pod postacią del5q(-) niskiego i pośrednio niskiego ryzyka według IPSS oraz leków demetylujących (azacytydyna, decytabina) w leczeniu pacjentów obciążonych ryzykiem pośrednim-2 i wysokim [36-38].

W badaniu 2. fazy przeprowadzonym u 148 chorych na MDS $z$ obecnością izolowanej del5q(-) wykazano, że lenalidomid powoduje uniezale $\dot{z}-$ nienie się od przetoczeń kkcz i eliminację klonu nowotworowego u znacznego odsetka leczonych [36]. Po 24 tygodniach obserwacji $67 \%$ pacjentów uniezależniło się od przetoczeń kkcz, a u $9 \%$ chorych doszło do zmniejszenia o co najmniej $50 \%$ konieczności transfuzji. Efekt terapii był szybki - mediana czasu do ustąpienia konieczności przetoczeń wynosiła 4,6 tygodnia. Mediana czasu utrzymywania się odpowiedzi klinicznej wynosiła 2 lata. Należy podkreślić, że u $45 \%$ leczonych chorych spośród 85 poddanych analizie stwierdzono całkowitą odpowiedź cytogenetyczną, niezależnie od złożoności wyjściowych aberracji chromosomowych; nie odnotowano przy tym zwiększenia ryzyka transformacji MDS do AML. To pierwszy tak spektakularny efekt działania farmakoterapii w eradykacji klonu nowotworowego obserwowany u chorych na MDS. Na podstawie wyników opisywanego badania lenalidomid został zatwierdzony w 2005 roku przez FDA do leczenia chorych na MDS zależnych od przetoczeń kkcz, Z grup niskiego i pośredniego-1 ryzyka według IPSS, przebiegającego $z$ del5q(-) jako izolowaną aberracją cytogenetyczną lub współistniejącą $z$ innymi zaburzeniami.

Kolejnym ważnym doniesieniem było opublikowanie w 2009 roku wyników badania AZA 001, w którym porównywano skuteczność azacytydyny (AZA) $z$ innymi standardowymi metodami leczenia stosowanymi w MDS - intensywną chemioterapią, podawaniem małych dawek arabinozydu cytozyny (Ara-C) oraz leczeniem objawowym [38]. Badaną grupę stanowili pacjenci, których mediana wieku wynosiła 69 lat, w większości przypadków chorujący na MDS o pośrednim-2 i wysokim ryzyku oraz chorzy na CMML. W badaniu wykazano, że w porównaniu $z$ leczeniem standardowym AZA niemal 2-krotnie wydłuża OS chorych na MDS $-24,5$ miesiąca versus 15 miesięcy $(\mathrm{p}=0,0001)$. Odsetek odpowiedzi całkowitych (CR, complete response) i częściowych (PR, partial response) wynosił odpowiednio $29 \%$ w grupie leczonej AZA i $12 \%$ wśród pacjentów otrzymujących standardową terapię. Działanie takie obserwowano niezależnie od wieku, odsetka blastów w szpiku i kariotypu. W grupie leczonej AZA stwierdzono niższy odsetek transformacji do AML, mniejsze zapotrzebowanie na kkcz i koncentrat krwinek płytkowych (kkp) oraz niższe ryzyko infekcji. Obecnie AZA jest zaaprobowana przez FDA i EMA do leczenia chorych na MDS $z$ pośrednim-2 $\mathrm{i}$ wysokim ryzykiem według IPSS oraz chorych na CMML.

Mimo wprowadzenia do terapii MDS nowych skutecznych leków, takich jak leki demetylujące i lenalidomid, efekty terapii, zwłaszcza u chorych na MDS o pośrednim i wysokim ryzyku, są niezadowalające. Trwa wiele prób klinicznych w celu oceny skuteczności łącznego zastosowania leków, na przykład AZA i lenalidomidu czy AZA $z$ inhibitorami deacetylazy histonów (parakrinostat, panobinostat, mocetinostat) [39]; w najbliższych latach będzie znana odpowiedź, czy mają one przewage 
nad monoterapią. Niestety, od 2006 roku żaden $z$ badanych leków nie spełnił kryteriów skuteczności pozwalających na rejestrację przez FDA i EMA dla chorych na MDS. Nadal jedyną metodą stwarzającą szansę wyleczenia jest allo-HSCT. Ze względu na zaawansowany wiek większości chorych na MDS dostępność tej opcji terapeutycznej stała się większa wraz $\mathrm{z}$ rozpowszechnieniem transplantacji ze zredukowanym kondycjonowaniem (RIC, reduced-intensity conditioning). Mimo wielu analiz retrospektywnych pytanie o optymalne leczenie cytoredukujące przed planowanym allo-HSCT pozostaje nierozstrzygnięte. Standardowym postępowaniem pozostaje konwencjonalna chemioterapia, ale wiele danych przemawia za podobną skutecznością (przy niższej toksyczności) terapii hipometylujacej [40-43]; być może, problem ten pozwolą rozwiązać wyniki randomizowanego badania służącego porównaniu AZA z konwencjonalną chemioterapią indukującą (NCT01812252).

Omawiając postępy w leczeniu chorych na MDS w ostatnich latach, należy wspomnieć o istotnej roli leczenia wspomagającego, przede wszystkim leków chelatujących (deferazyroks), a także agonistów receptora dla trombopoetyny (eltrombopagu i romiplostymu). Deferazyroks stosowany u chorych na MDS zależnych od transfuzji powoduje istotne obniżenie stężenia ferrytyny w osoczu, a także poprawę parametrów morfologii krwi u części leczonych. Należy jednak brać pod uwagę istotną hepato- i nefrotoksyczność leku [35, 44]. Próby zastosowania eltrombopagu i romiplostymu u chorych na MDS i małopłytkowość wykazały ich skuteczność w zakresie zwiększenia liczby płytek i obniżenia ryzyka krwawienia, natomiast romiplostym powodował zwiększenie liczby blastów, co spowodowało przerwanie próby klinicznej $[45,46]$.

\section{Podsumowanie}

W ostatnich kilku latach dokonał się duży postęp w zakresie wiedzy na temat patogenezy MPN $B C R-A B L 1(-)$ i MDS. Na szczególną uwagę zasługuje identyfikacja nowego onkogenu - CALR, której mutacje są charakterystyczne dla ET i PMF przebiegających bez mutacji w genach JAK2 lub/i MPL. Bardzo istotna jest również identyfikacja licznych mutacji genów zaangażowanych $\mathrm{w}$ regulację mechanizmów epigenetycznych w przebiegu PMF i MDS oraz próby określenia ich znaczenia rokowniczego.

Duży postęp zaistniał również w szacowaniu prognozowania przebiegu klinicznego tych chorób. W obecnie obowiązujących wskaźnikach rokowni- czych, w tym DIPSS plus dla PMF i IPSS-R dla MDS, szczególną wagę przykłada się do obecności zmian cytogenetycznych i molekularnych, a tym samym dokładniej dyskryminuje grupy ryzyka. Pozwala to na lepsze kwalifikowanie chorych do różnych rodzajów terapii, a zwłaszcza do procedury allo-HSCT.

Podsumowując zmiany, jakie zaszły w ostatnich latach $\mathrm{w}$ farmakoterapii, należy podkreślić zarejestrowanie pierwszego leku z grupy inhibitorów kinaz JAK - ruksolitynibu - do leczenia chorych na PMF obciążonych ryzykiem pośrednim-2 i wysokim oraz chorych na PV z opornością lub nietolerancją HU. Od 2006 roku żaden nowy lek nie został zarejestrowany do leczenia pacjentów z MDS, natomiast lenalidomid i AZA potwierdziły swoją skuteczność.

\section{Piśmiennictwo}

1. Vardiman J.W., Thiele J., Arber D.A. i wsp. The 2008 revision of the World Health Organization (WHO) classification of myeloid neoplasms and acute leukemia: rationale and important changes. Blood 2009; 114: 937-951.

2. James C., Ugo V., Le Couedic J.P. i wsp. A unique clonal JAK2 mutation leading to constitutive signalling causes polycythaemia vera. Nature 2005; 434: 1144-1148.

3. Scott L.M., Tong W., Levine R.L. i wsp. JAK2 exon 12 mutations in polycythemia vera and idiopathic erythrocytosis. N. Engl. J. Med. 2007; 356: 459-468.

4. Nangalia J., Massie C.E., Baxter E.J. i wsp. Somatic CALR mutations in myeloproliferative neoplasms with nonmutated JAK2. N. Engl. J. Med. 2013; 369: 2391-2405.

5. Klampfl T., Gisslinger H., Harutyunyan A.S. i wsp. Somatic mutations of calreticulin in myeloproliferative neoplasms. N. Engl. J. Med. 2013; 369: 2379-2390.

6. Luo B., Lee A.S. The critical roles of endoplasmic reticulum chaperones and unfolded protein response in tumorigenesis and anticancer therapies. Oncogene 2013; 32: 805-818.

7. Andrikovics H., Krahling T., Balassa K. i wsp. Distinct clinical characteristics of myeloproliferative neoplasms with calreticulin mutations. Haematologica 2014; 99: 1184-1190.

8. Rotunno G., Mannarelli C., Guglielmelli P. i wsp. Impact of calreticulin mutations on clinical and hematological phenotype and outcome in essential thrombocythemia. Blood 2014; 123: 1552-1555.

9. Runni E., Pietra D., Ferretti V. i wsp. JAK2 or CALR mutation status defines subtypes of essential thrombocythemia with substantially different clinical course and outcomes. Blood 2014; 123 : 1544-1551.

10. Tefferi A., Guglielmelli P., Lasho T.L. i wsp. CALR and ASXL1 mutations-based molecular prognostication in primary myelofibrosis: an international study of 570 patients. Leukemia 2014; 28: 1494-1500.

11. Vannucchi A.M., Lasho T.L., Guglielmelli P. i wsp. Mutations and prognosis in primary myelofibrosis. Leukemia 2013; 27 : 1861-1869.

12. Guglielmelli P., Lasho TL., Rotunno G. i wsp. The number of prognostically detrimental mutations and prognosis in primary myelofibrosis: an international study of 797 patients. Leukemia 2014; 28: 1804-1810. 
13. Nangalia J., Green T.R. The evolving genomic landscape of myeloproliferative neoplasms. Hematology Am. Soc. Hematol. Educ. Program 2014; 5: 287-296.

14. Cervantes F., Dupriez B., Pereira A. i wsp. New prognostic scoring system for primary myelofibrosis based on a study of the International Working Group for Myelofibrosis Research and Treatment. Blood 2009; 113: 2895-2901.

15. Passamonti F., Cervantes F., Vannucchi A.M. i wsp. A dynamic prognostic model to predict survival in primary myelofibrosis: a study by the IWG-MRT (International Working Group for Myeloproliferative Neoplasms Research and Treatment). Blood 2010; 115: 1703-1708.

16. Gangat N., Caramazza D., Vaidya R. i wsp. DIPSS-Plus: a refined Dynamic International Prognostic Scoring System (DIPSS) for primary myelofibrosis that incorporates prognostic information from karyotype, platelet count and transfusion status. J. Clin. Oncol. 2011; 29: 392-397.

17. Vannucchi A.M., Guglielmelli P., Rotunno G. i wsp. Mutation-Enhanced International Prognostic Scoring System (MIPSS) for primary myelofibrosis: an AGIMM \& IWG-MRT Project. Blood 2014; 124: abstrakt 405.

18. Tefferi A., Guglielmelli P., Finke C. i wsp. Integration of mutations and karyotype towards a Genetics-Based Prognostic Scoring System (GPSS) for primary myelofibrosis. Blood 2014; 124: abstrakt 406.

19. Verstovsek S., Mesa R.A., Gotlib J. i wsp. Efficacy, safety, and survival with ruxolitinib in patients with myelofibrosis: results of a median 3-year follow-up of COMFORT-I. Haematologica 2015; 100: 479-488.

20. Cervantes F., Vannucchi A.M., Kiladjian J.J. i wsp. Three-year efficacy, safety, and survival findings from COMFORT-II, a phase 3 study comparing ruxolitinib with best available therapy for myelofibrosis. Blood 2013; 122: 4047-4053.

21. Geyer H.L., Mesa R.A. Therapy for myeloproliferative neoplasms: when, which agent, and how? Blood 2014; 124: 3529-3537.

22. Vannucchi A.M., Kiladjian J.J., Griesshammer M. i wsp. Ruxolitinib versus standard therapy for the treatment of polycythemia vera. N. Engl. J. Med. 2015; 372: 426-435.

23. Silver R.T. Are all interferons the same for therapy in polycythemia vera? Clin. Lymphoma Myeloma Leuk. 2013; 13 (supl. 2): S305-S306.

24. Kiladjian J.J., Mesa R.A., Hoffman R. The renaissance of interferon therapy for the treatment of myeloid malignancies. Blood 2011; 117: 4706-4715.

25. Bejar R., Stevenson K., Abdel-Wahab O. i wsp. Clinical effect of point mutations in myelodysplastic syndromes. N. Engl. J. Med. 2011; 364: 2496-2506.

26. Papaemmanuil E., Gerstung M., Malcovati L. i wsp.; Chronic Myeloid Disorders Working Group of the International Cancer Genome Consortium. Clinical and biological implications of driver mutations in myelodysplastic syndromes. Blood 2013; 122: 3616-3627.

27. Haferlach T., Nagata Y., Grossmann V. i wsp. Landscape of genetic lesions in 944 patients with myelodysplastic syndromes. Leukemia 2014; 28: 241-247.

28. Saft L., Karimi M., Ghaderi M. i wsp. p53 protein expression independently predicts outcome in patients with lower-risk myelodysplastic syndromes with $\operatorname{del}(5 q)$. Haematologica 2014; 99: 1041-1049.

29. Greenberg P., Cox C., LeBeau M. i wsp. International scoring system for evaluating prognosis in myelodysplastic syndromes. Blood 1997; 89: 2079-2088; Errata: Blood 1998; 91: 1100.
30. Malcovati L., Porta M.G., Pascutto C. i wsp. Prognostic factors and life expectancy in myelodysplastic syndromes classified according to WHO criteria: a basis for clinical decision making. J. Clin. Oncol. 2005; 23: 594-603.

31. Greenberg P.L., Tuechler H., Schanz J. i wsp. Revised international prognostic scoring system for myelodysplastic syndromes. Blood 2012; 120: 2454-2465.

32. Mishra A., Corrales-Yepez M., Ali N.A. i wsp. Validation of the revised International Prognostic Scoring System in treated patients with myelodysplastic syndromes. Am. J. Hematol. 2013; 88: $566-570$.

33. Neukirchen J., Lauseker M., Blum S. i wsp. Validation of the revised international prognostic scoring system (IPSS-R) in patients with myelodysplastic syndrome: a multicenter study. Leuk. Res. 2014; 38: 57-64.

34. Della Porta M.G., Alessandrino E.P., Bacigalupo A. i wsp. Predictive factors for the outcome of allogeneic transplantation in patients with MDS stratified according to the revised IPSS-R. Blood 2014; 123: 2333-2342.

35. Greenberg P.L., Stone R.M., Bejar R. i wsp. Myelodysplastic syndromes, version 2.2015 featured updates to the NCCN guidelines. JNCCN 2015; 13: 261-271.

36. List A., Dewald G., Bennett J. i wsp. Lenalidomide in the myelodysplastic syndrome with chromosome $5 q$ deletion. N. Engl. J. Med. 2006; 355: 1456-1465.

37. Kantarjian H., Oki Y., Garcia-Manero G. i wsp. Results of a randomized study of 3 schedules of low-dose decitabine in higher-risk myelodysplastic syndrome and chronic myelomonocytic leukemia. Blood 2007; 109: 52-57.

38. Fenaux P., Mufti G.J., Hellstrom-Lindberg E. i wsp. Efficacy of azacitidine compared with that of conventional care regimens in the treatment of higher-risk myelodysplastic syndromes: a randomised, open-label, phase III study. Lancet Oncol. 2009; 10: 223-232.

39. Bejar R., Steensma D.P. Recent developments in myelodysplastic syndromes. Blood 2014; 18: 2793-2803.

40. Atallah E., Bylow K., Troy J. i wsp. Treatment of older patients with high-risk myelodysplastic syndromes (MDS): the emerging role of allogeneic hematopoietic stem cell transplantation (allo-HSCT). Curr. Hematol. Malig. Rep. 2014; 1: 57-65.

41. Damaj G., Duhamel A., Robin M. i wsp. Impact of azacitidine before allogeneic stem-cell transplantation for myelodysplastic syndromes: a study by the Société Française de Greffe de Moelleet de Thérapie-Cellulaire and the Groupe-Francophone des Myélodysplasies. J. Clin. Oncol. 2012; 30: 4533-4540.

42. Gerds A.T., Gooley T.A., Estey E.H. i wsp. Pretransplantation therapy with azacitidine vs induction chemotherapy and post-transplantation outcome in patients with MDS. Biol. Blood Marrow Transplant. 2012; 18: 1211-1218.

43. Cutler C. Timing of allogeneic stem cell transplantation for myelodysplastic syndromes and aplastic anemia. Hematology Am. Soc. Hematol. Educ. Program 2014; 5: 77-81.

44. Maurillo L., Breccia M., Buccisano F. i wsp. Deferasirox chelation therapy in patients with transfusion-dependent MDS: a 'real-world' report from two regional Italian registries: Gruppo Romano Mielodisplasie and Registro Basilicata. Eur. J. Haematol. 2015 Mar 12. doi: 10.1111/ejh.12476 [złożone do druku].

45. Sekeres M.A., Gerds A.T. Established and novel agents for myelodysplastic syndromes. Hematology Am. Soc. Hematol. Educ. Program 2014; 5: 82-89.

46. Giagounidis A., Mufti G.J., Fenaux P. i wsp. Results of a randomized, double-blind study of romiplostim versus placebo in patients with low/intermediate-1-risk myelodysplastic syndrome and thrombocytopenia. Cancer 2014; 120: 1838-1846. 